\title{
The Role of Ghrelin in the Regulation of Food Intake in Patients with Obesity and Anorexia Nervosa
}

\author{
I. DOSTÁLOVÁ ${ }^{1,2}$, M. HALUZÍ́K ${ }^{2}$ \\ ${ }^{1}$ Institute of Endocrinology, Prague, ${ }^{2}$ Third Department of Medicine, First Faculty of Medicine and \\ General University Hospital, Charles University, Prague, Czech Republic
}

Received November 14, 2007

Accepted January 10, 2008

On-line April 1, 2008

\begin{abstract}
Summary
Gastrointestinal hormones play an important role in the neuroendocrine regulation of food intake and postprandial satiety. Ghrelin is a 28 -amino acid orexigenic peptide produced mainly by the stomach that is involved in both the long-term regulation of body weight and the short-term regulation of postprandial satiety. Impairments in ghrelin secretion may in concert with other factors play an important role in the development of both obesity and anorexia nervosa. Despite an intensive research the critical factors regulating physiological postprandial ghrelin response in healthy individuals and its modification by the presence of obesity and anorexia nervosa are only partially understood. The potential contribution of ghrelin to the differences of diet- vs. surgical-induced weight losses in morbidly obese patients is now also being recognized. The aim of this review is to summarize the current knowledge about the physiology and pathophysiology of ghrelin and to discuss its potential in the prevention and/or treatment of obesity and anorexia nervosa.
\end{abstract}

\section{Key words}

Ghrelin • Obesity • Anorexia nervosa • Macronutrients • Obesity surgery

\section{Corresponding author}

I. Dostálová, Third Department of Medicine, First Medical Faculty, Charles University, U Nemocnice 1, 12808 Prague 2, Czech Republic. E-mail: idostalova@centrum.cz

\section{Introduction}

The global increase in the prevalence of obesity and its associated comorbidities has stimulated intensive research focused on better understanding of energy metabolism regulation and the possibilities to prevent and/or treat obesity. Clustering of obesity with other pathologies such as arterial hypertension, dyslipidemia, hypercoagulation state and insulin resistance is commonly referred to as insulin resistance syndrome (Reaven 2006). Numerous large scale studies have demonstrated that the presence of insulin resistance syndrome markedly increases cardiovascular morbidity and mortality (Frayn and Coppack 1992).

The etiology of obesity is very complex and is based upon the interplay of genetic and environmental factors. It has been suggested that decreased satiety perception represents an important risk factor for the development of obesity (Delgado-Aros et al. 2004). Obese subjects have delayed onset of satiety after meal consumption which might be due to alterations in hormonal responses to food intake (Schwartz and Morton 2002). Since existing therapeutic strategies to achieve and maintain clinically significant weight loss remain limited, modulation of satiety perception through the changes of gastrointestinal (GI) hormone secretion represents a promising approach to prevent and/or treat this disease and its complications (Le Roux and Bloom 2005).

On the other side of nutritional spectrum, paradoxical increase in the incidence of anorexia nervosa (AN) is alarming. Both the trend of modern societies, that 
more slim means more success, and unfavorable social conditions partly contribute to the initiation of this severe disorder. AN affects about $0.3 \%$ of young girls with a mortality of $6 \%$ per decade (Dardennes et al. 2007). Patients with AN are characterized by the abnormal eating behavior and inadequate perception of body weight and numerous metabolic and endocrine abnormalities (Housová et al. 2005, Doležalová et al. 2007). Patients with severe forms of AN suffer from chronic malnutrition (Casper 1996), but the exact etiopathogenesis of this disorder is still unknown. Gut hormones have been under an intensive research as hot candidates on regulators of appetite and satiety in these patients.

\section{The role of gastrointestinal hormones in the regulation of food intake}

Complex physiological mechanisms have evolved to control food intake in mammals. For most people, the amount and composition of food eaten varies considerably from meal to meal and from day to day. Food consumption and ingested nutrients stimulate the release of a variety of hormones from enteroendocrine cells throughout the gut and pancreas. Most of these molecules have the potential to modulate food intake. GI hormone signaling results in three major outcomes: meal termination, inhibition of subsequent meal intake, and orexigenic modulation (Moran 2006). Overall, GI hormones constitute a significant part of the complex neuroendocrine regulation of energy balance. Most of GI tract hormones increase satiety and decrease food intake. The only known exception is a hormone ghrelin that has the opposite effects. Here we review the current knowledge about the physiology and pathophysiology of this hormone with special focus on its possible role in the etiopathogenesis of obesity and anorexia nervosa.

\section{Ghrelin: physiology and pathophysiology}

Ghrelin has been discovered by Kojima et al. (1999) as a natural ligand of the growth hormone (GH) secretagogue (GHS) receptor type 1a (GHS-R1a). Subsequently, ghrelin turned out to exert more pleiotropic actions, consistent with the widespread distribution of ghrelin and GHS-R expression in central and peripheral tissues. The GHS-R is highly expressed in the hypothalamus, including nucleus arcuatus, but is also found in the brainstem, pituitary, GI tract, adipose tissue and other peripheral tissues (Petersenn 2002).
At present ghrelin is the only known GI hormone that increases food intake. Plasma ghrelin levels are inversely correlated with body weight and rise following weight loss in humans (Cummings et al. 2002). The major source of circulating ghrelin is the stomach, although ghrelin mRNA and immunoreactivity are also found in other regions of the GI tract (Date et al. 2000). Ghrelin is composed of 28 amino acids with an acyl side chain attached to the serine residue at position 3 . This acyl group is crucial for ghrelin's orexigenic and GH-releasing actions (Kojima et al. 1999). However, it has been suggested that desacylated ghrelin has other biological functions mediated by separate GHS-R subtypes (Baldanzi et al. 2002, Mackelvie et al. 2007, Giovambattista et al. 2008). The orexigenic effects of peripheral ghrelin are mediated via the central nervous system through activation neurons in the hypothalamic arcuate and paraventricular nuclei (Ruter et al. 2003, Janas-Kozik et al. 2007). The orexigenic effects of ghrelin are at least partially mediated via NPY and agouti-related protein (AgRP) (Nakazato et al. 2001, Chen et al. 2004). The recently described product of the ghrelin gene, named obestatin, was initially postulated to antagonize ghrelin orexigenic action in rats (Zhang et al. 2005). These initial findings were, however, disclaimed by the majority of later studies (Holst et al. 2007, Nogueiras et al. 2007, Yamamoto et al. 2007).

Considerable evidence implicates the role of ghrelin in mealtime hunger and meal initiation. Its circulating levels decrease with feeding and increase before meals, achieving concentrations sufficient to stimulate hunger and food intake (Cummings et al. 2001). Preprandial ghrelin surges occur before every meal on various fixed feeding schedules and also in individuals initiating meals voluntarily without time- or food-related cues. Ghrelin injections stimulate food intake rapidly and transiently, primarily by increasing appetitive feeding behavior and the number of meals (Cummings 2006). Consistent with the prediction of ghrelin as a physiological meal initiator in humans, intragastric infusion of a glucose solution in rats and humans significantly suppresses plasma ghrelin levels, whereas intragastric infusion of the same volume of water does not suppress ghrelin (Tschop et al. 2000, Shiiya et al. 2002, Williams et al. 2003). However, non-caloric fibre reduces plasma ghrelin to the same extent as a caloric mixed meal in healthy women (Nedvídková et al. 2003).

The short-term overfeeding with high-fat diet in normal-weight healthy subjects reduces ghrelin levels, 
similarly as seen in obesity, suggesting that decreased ghrelin levels may precede the development of significant adiposity (Robertson et al. 2004). Weight loss induced by diet and exercise leads to a compensatory increase in circulating ghrelin in normal-weight healthy women. In these studies, changes in body weight, body composition and resting metabolic rate occurred prior to changes in circulating ghrelin levels (Leidy et al. 2004).

The mechanisms controlling ghrelin secretion during fasting and postprandial suppression are unknown (Nakai et al. 2003). In healthy subjects, sham-feeding (i.e. only chewing of meal without swallowing) decreases ghrelin levels to a similar extent as regular feeding, suggesting vagal involvement in the postprandial ghrelin fall (Arosio et al. 2004, Heath et al. 2004). The neural, but not the neurohumoral, branch of the sympathetic nervous system can directly stimulate ghrelin secretion (Mundinger et al. 2006).

Despite an intensive research it is still not completely clear which parts of digestive tract regulate ghrelin secretion. In some studies, neither gastric nor duodenal exposure to nutrients was required for nutrientrelated suppression of ghrelin (Williams et al. 2003, Cummings 2006). Ghrelin secretion was rather the result of post-ingestive increases in jejunal osmolarity (information probably relayed to the foregut via enteric nervous signaling), as well as from insulin surges, respectively (Cummings 2006). However, it is conceivable that ghrelin suppression can be achieved equally from various parts of the intestine coming in contact with nutrients (Overduin et al. 2005).

Specific effects of respective nutrients and caloric content of the meal on ghrelin levels still need to be clarified. In humans, the level of postprandial ghrelin suppression is proportional to ingested caloric load, but the recovery of plasma ghrelin is not a critical determinant of intermeal intervals in healthy individuals (Callahan et al. 2004). In healthy subjects, a longer fasting period during the day (i.e. irregular meal pattern typical for several eating disorders) increases ghrelin concentration, but does not affect postprandial ghrelin response to a mixed meal (Briatore et al. 2006). Ghrelin suppression in healthy individuals depends on the macronutrient content of meals (Erdmann et al. 2003). Most studies have used mixed or carbohydrate-rich test meals, which classically suppress ghrelin levels and measurements of hunger (Cummings et al. 2002, Shiiya et al. 2002, Callahan et al. 2004). Some authors have found that protein- and fat-rich meals increase ghrelin levels (Erdmann et al. 2003, 2004). In healthy humans, carbohydrates suppressed ghrelin to the greatest extent, whereas fat was the least effective (Monteleone et al. 2003). Glucose load inhibits ghrelin secretion after either oral or intravenous administration (Shiiya et al. 2002, McCowen et al. 2002, Nakagawa et al. 2002), whereas intravenous free fatty acid or arginine load does not affect circulating ghrelin levels in humans (Mohlig et al. 2002). Theoretically, weak suppression of ghrelin by ingested lipids could be one of the mechanisms underlying highfat diet-induced weight gain (Astrup 2002).

Several studies focused on the possible role of insulin in the regulation of ghrelin levels. Although high doses of insulin, or combination of insulin and glucose reduced plasma ghrelin levels in some studies (Mohlig et al. 2002, Saad et al. 2002, Flanagan et al. 2003), other data from studies in insulin-deficient patients with type 1 diabetes indicate that increase in insulin levels after ingestion is not required for meal-related ghrelin suppression (Murdolo et al. 2003). Taken together, postprandial suppression of ghrelin in many studies goes in parallel with increase in glucose and insulin levels (Cummings et al. 2001, Tchop et al. 2001, Shiiya et al. 2002, Monteleone et al. 2003, Erdmann et al. 2004). However, the regulating role of insulin on postprandial ghrelin suppression is rather additive.

\section{Ghrelin and obesity}

Total and active fasting ghrelin levels are decreased in human obesity (Marzullo et al. 2006), which might represent a compensatory response to a sustained positive energy balance (Cummings and Shannon 2003). Among obese otherwise healthy adults plasma ghrelin concentrations are lower in more insulin-resistant subjects relative to equally obese individuals with relatively higher insulin sensitivity (McLaughlin et al. 2004). Suppression of active form of ghrelin in obese subjects during hyperinsulinemic-euglycemic clamp is inversely related to insulin resistance (St. Pierre et al. 2007). Obese subjects are not resistant to the effects of ghrelin administration (Cremonini et al. 2006) and ghrelin could play an important role in the endocrine abnormalities commonly present in obesity (Muccioli et al. 2002, Cummings and Shannon 2003). Obese people appear to be more sensitive to the appetite-stimulating effects of exogenous ghrelin than normal-weight subjects and inhibition of circulating ghrelin could be a useful therapeutic approach in the treatment of obesity (Druce $e t$ 
al. 2004). However, the effect of ghrelin administration on glucose and insulin levels is not direct and dosedependent and its overall mechanism is still not completely clear (Alvarez-Castro et al. 2006, Tassone et al. 2003).

Some studies have shown a complete lack of postprandial ghrelin suppression in obese patients (English et al. 2002, Morpurgo et al. 2003, Moran et al. 2004). Other studies have found normal (Weigle et al. 2003, Romon et al. 2006) or incomplete (Greenman et al. 2004, Marzullo et al. 2006) postprandial ghrelin suppression in obese (Table 1). The postprandial ghrelin response in obese subjects is, in contrast to healthy individuals, independent of caloric content and macronutrient composition of the meal (Table 1). The reduced ghrelin response or its complete insensitivity to meal-induced suppression may contribute to the resistance to weight loss in some of obese patients (Greenman et al. 2004).

Studies focused on the effect of diet-induced weight loss on postprandial ghrelin responses have generally yielded inconsistent results (Weigle et al. 2003, Morpurgo et al. 2003, Moran et al. 2004, Romon et al. 2006) (Table 1). In some studies, weight loss restored some features of the normal regulatory role of ghrelin on hunger and meal initiation. It seems that particular amount of weight loss (more than $5 \%$ of initial body weight) rather than duration of weight-reduction program, is important for the restoration of postprandial ghrelin response (Table 1). Diet-induced weight loss preferentially improves plasma ghrelin response to a carbohydrate test meal in obese women (Romon et al. 2006), suggesting that the improvement in insulin sensitivity could play a role. Alterations in fat-free mass with weight loss may also be involved in ghrelin regulation in obese subjects. Overall, the changes in ghrelin levels could serve as an integrative signal reflecting changes in both fat and fat-free mass to hypothalamic centers controlling energy homeostasis (Purnell et al. 2007).

While baseline ghrelin levels generally increase in response to diet-induced weight loss (Weigle et al. 2003, Romon et al. 2006), surgically-induced weight loss (e.g. gastric bypass) decrease ghrelin levels (Morinigo et al. 2004). It has been suggested that decreased ghrelin levels after obesity surgery may be involved in the mechanisms inducing sustained weight loss in contrast to more frequent relapses in obese patients with diet- induced weight loss.

It is also important to note that different surgical procedures are unequally effective in suppression of ghrelin. For example, Roux-en-Y gastric bypass (RYGBP) markedly suppresses fasting ghrelin levels in morbidly obese patients. The reduction of ghrelin after 6 weeks after RYGBP was described (Morinigo et al. 2004). Prolonged weight losses 9-31 months after RYGBP lead to further significant reduction of circulating ghrelin in obese patients (Cummings et al. 2002, Geloneze et al. 2003, Leonetti et al. 2003, Tritos et al. 2003). Paradoxical decrease in fasting plasma ghrelin after RYGBP surgery occurs not only in patients with massive weight losses (Cummings et al. 2002, Geloneze et al. 2003), but also in patients with weight loss comparable to those achieved by diet (Morinigo et al. 2004). These findings raise the possibility that this bariatric surgical procedure reduces weight at least in part by suppressing ghrelin production and its appetitestimulating effects.

In contrast to gastric bypass prolonged weight loss one year after laparoscopical adjustable gastric banding results in a slight but significant rise in plasma ghrelin concentrations (Hanusch-Enserer et al. 2004, Leonetti et al. 2003). These findings are consistent with the hypothesis that suppression of ghrelin is one of the mechanisms explaining why gastric bypass can reduce body weight more effectively than gastric banding. Nevertheless, the mechanism by which gastric bypass leads to a reduction in ghrelin levels is still not completely clear. It has been suggested that a permanent absence of food in the empty stomach resulting from gastric bypass could cause a continuous stimulatory signal that ultimately suppresses ghrelin production through a process of overriding inhibition (Cummings et al. 2002). A modification in vagal control of fundus and anthrum cells of the stomach because of a gastric bypass procedure could be involved in paradoxical lowering of ghrelin production.

Another obesity surgery procedure - sleeve gastrectomy - markedly suppresses ghrelin levels probably due to resection of gastric fundus which is the most important site of ghrelin production in humans (Langer et al. 2005, Kotidis et al. 2006). The reduction of ghrelin levels after sleeve gastrectomy remains stable at for 6 months after surgery, which may contribute to superior weight loss after this procedure when compared with gastric banding (Langer et al. 2005). 
Table 1. Postprandial response of total ghrelin in obese patients.

\begin{tabular}{|c|c|c|c|c|c|}
\hline $\begin{array}{l}\text { Postprandial } \\
\text { ghrelin } \\
\text { response before } \\
\text { weight loss }\end{array}$ & $\begin{array}{l}\text { Test meal } \\
\text { (caloric value, } \\
\text { macronutrient } \\
\text { composition) }\end{array}$ & $\begin{array}{l}\text { Weight-reduction } \\
\text { program } \\
\text { (duration, daily } \\
\text { caloric value, } \% \text { of } \\
\text { daily energy in } \\
\text { macronutrients) }\end{array}$ & $\begin{array}{l}\text { Average } \\
\text { weight loss } \\
\text { (percent of } \\
\text { initial } \\
\text { weight) }\end{array}$ & $\begin{array}{l}\text { Postprandial } \\
\text { ghrelin } \\
\text { response after } \\
\text { weight loss }\end{array}$ & Study \\
\hline$\times$ & $\begin{array}{l}714 \mathrm{kcal} \\
57 \% \mathrm{C}, 12 \% \mathrm{P} \\
31 \% \mathrm{~F}\end{array}$ & no & - & - & $\begin{array}{l}\text { English } \\
\text { et al. } 2002\end{array}$ \\
\hline$\times$ & $\begin{array}{l}550 \mathrm{kcal} \\
48 \% \mathrm{C}, 33 \% \mathrm{~F}, \\
19 \% \mathrm{P}\end{array}$ & $\begin{array}{l}3 \mathrm{wk} \\
1200-1800 \mathrm{kcal} / \text { day } \\
21 \% \mathrm{P}, 53 \% \mathrm{C}, \\
26 \% \mathrm{~F}\end{array}$ & $5.6 \%$ & $=$ & $\begin{array}{l}\text { Morpurgo et } \\
\text { al. } 2003\end{array}$ \\
\hline$x$ & $\begin{array}{l}646 \mathrm{kcal} \\
31 \% \mathrm{P}, 14 \% \mathrm{~F} \\
55 \% \mathrm{C}\end{array}$ & $\begin{array}{l}12 \mathrm{wk} \\
1435 \mathrm{kcal} / \mathrm{day} \\
30 \% \mathrm{P}, 40 \% \mathrm{C}, \\
30 \% \mathrm{~F}\end{array}$ & $7.5 \%$ & $\downarrow$ & $\begin{array}{l}\text { Moran } \\
\text { et al. } 2004\end{array}$ \\
\hline$\times$ & $\begin{array}{l}646 \mathrm{kcal} \\
11 \% \mathrm{P}, 15 \% \mathrm{~F} \\
76 \% \mathrm{C}\end{array}$ & $\begin{array}{l}12 \mathrm{wk} \\
1435 \mathrm{kcal} / \text { day } \\
55 \% \mathrm{C}, 15 \% \mathrm{P}, \\
30 \% \mathrm{~F}\end{array}$ & & $\downarrow$ & \\
\hline$\downarrow$ & - & $\begin{array}{l}12 \text { wk } \\
\text { ad libitum } \\
15 \% \mathrm{~F}, 65 \% \mathrm{C}, \\
20 \% \mathrm{P}\end{array}$ & $5 \%$ & $=$ & $\begin{array}{l}\text { Weigle } \\
\text { et al. } 2003\end{array}$ \\
\hline$\downarrow$ shorter & $\begin{array}{l}300 \mathrm{kcal} \\
75 \mathrm{~g} \text { of dextrose }\end{array}$ & no & - & - & $\begin{array}{l}\text { Greenman et } \\
\text { al. } 2004\end{array}$ \\
\hline$\downarrow$ & $\begin{array}{l}400 \mathrm{kcal} \\
91 \% \mathrm{~F}, 5,5 \% \mathrm{C} \text {, } \\
4.5 \% \mathrm{P}\end{array}$ & & & & \\
\hline$\downarrow$ & $\begin{array}{l}240 \mathrm{kcal} \\
84 \% \mathrm{P}, 5 \% \mathrm{C}, \\
11 \% \mathrm{~F}\end{array}$ & & & & \\
\hline$\downarrow$ & $\begin{array}{l}813 \mathrm{kcal} \\
79 \% \mathrm{~F}, 18 \% \mathrm{P} \\
3 \% \mathrm{C}\end{array}$ & $\begin{array}{l}7 \mathrm{wk} \\
800 \mathrm{kcal} / \text { day } \\
20 \% \mathrm{C}, 50 \% \mathrm{P}\end{array}$ & $10.5 \%$ & $=$ & $\begin{array}{l}\text { Romon } \\
\text { et al. } 2006\end{array}$ \\
\hline$\downarrow$ & $\begin{array}{l}813 \mathrm{kcal} \\
81 \% \mathrm{C}, 18 \% \mathrm{P} \\
1 \% \mathrm{~F}\end{array}$ & $30 \% \mathrm{~F}$ & & $\downarrow \downarrow$ & \\
\hline$\downarrow<13 \%$ & $\begin{array}{l}500 \mathrm{kcal} \\
53 \% \mathrm{C}, 30 \% \mathrm{~F}, \\
17 \% \mathrm{P}\end{array}$ & no & - & - & $\begin{array}{l}\text { Marzullo } \\
\text { et al. } 2006\end{array}$ \\
\hline$\downarrow<14 \%$ & $\begin{array}{l}500 \mathrm{kcal} \\
28 \% \mathrm{C}, 55 \% \mathrm{~F}, \\
17 \% \mathrm{P}\end{array}$ & & & & \\
\hline$\downarrow<16 \%$ & $\begin{array}{l}500 \mathrm{kcal} \\
45 \% \mathrm{C}, 25 \% \mathrm{~F}, \\
30 \% \mathrm{P}\end{array}$ & & & & \\
\hline
\end{tabular}

C - carbohydrates, F - fat, P - protein. $\times$ lack of suppression seen in healthy controls; $\downarrow$ postprandial suppression; $\downarrow \downarrow$ greater suppression than before weight reduction; = the same postprandial response as before weight reduction; $\downarrow<15 \%$ suppression, but about $15 \%$ less than in healthy controls 


\section{Ghrelin and anorexia nervosa}

Fasting ghrelin levels are elevated in both restrictive and binge/purge form of $\mathrm{AN}$ and return to normal levels after partial weight recovery (Otto et al. 2001, Tanaka et al. 2003, Misra et al. 2005, Nakahara et al. 2007) or even overburst to values lower than in controls after 3-6 months of realimentation therapy (Janas-Kozik et al. 2007). High ghrelin levels in AN appear to be a compensatory mechanism to increase caloric intake and induce a state of positive energy balance. Both body mass index and the bingeeating/purging behavior influence fasting ghrelin levels in patients with AN (Tanaka et al. 2003, Troisi et al. 2005, Janas-Kozik et al. 2007). Reduced food intake in patients with AN despite chronically increased ghrelin levels thus could reflect a decreased sensitivity to ghrelin effects (Misra et al. 2005). Several studies have shown that patients with AN are less sensitive to ghrelin administration in terms of GH response and appetite than healthy women (Broglio et al. 2004, Miljic et al. 2006). Postprandial ghrelin levels in patients with AN remain high after consumption of a $585 \mathrm{kcal}$ solid mixed meal (32.6 g fat, $17.6 \mathrm{~g}$ protein, $50 \mathrm{~g}$ carbohydrate) and do not fall even two hours after meal consumption (Nedvídková et al. 2003), whereas $250 \mathrm{ml}$ fluid meal of $250 \mathrm{kcal}(8.3 \mathrm{~g}$ fat, $9.4 \mathrm{~g}$ protein, $34.4 \mathrm{~g}$ carbohydrate) (Otto et al. 2005) as well as a $400 \mathrm{kcal}$ standard test meal (Nakahara et al. 2007) suppresses plasma ghrelin in patients with AN. Based on the published data, it can not be clearly concluded whether the postprandial ghrelin response in AN depends on caloric content, total volume or macronutrient composition of a meal. Suppressive effect of glucose on active (octanoylated) ghrelin secretion is preserved in adult patients with AN (Nakai et al. 2003, Hotta et al. 2004, Harada et al. 2008), but not in adolescent girls with AN (Misra et al. 2004). Ghrelin response to glucose administration in patients with AN also depends on insulin sensitivity and eating behavior (Tanaka et al. 2003).

The changes of ghrelin concentrations in obesity are opposite to those in AN, suggesting that ghrelin is a good marker of nutritional status (Soriano-Guillen et al. 2004). The lack of suppression of ghrelin secretion after a meal may be a critical factor in the pathophysiology of both obesity and eating disorders. Abnormalities in the release of ghrelin or insensitivity to its effects may be involved in alterations of food intake in both obesity and anorexia nervosa (Date et al. 2005).

\section{Conclusion and perspectives}

It can be summarized that ghrelin, a gut hormone with orexigenic effect, is markedly increased in patients with AN and significantly reduced in obese subjects. The secretion of ghrelin in stomach is stimulated by the combination of neural (vagus), mechanical (distension), chemical (osmolarity; caloric content and macronutrient composition of the meal) and hormonal (insulin) factors with unknown priority. The expected levels of fasting total plasma ghrelin levels are more than $1000 \mathrm{pg} / \mathrm{ml}$ in patients with $\mathrm{AN}$, less than $400 \mathrm{pg} / \mathrm{ml}$ in obese subjects and in a range of $400-1000 \mathrm{pg} / \mathrm{ml}$ in healthy normalweight subjects. Postprandially, ghrelin levels are suppressed in dependence of caloric content and macronutrient composition of the meal in healthy subjects. In both obese and AN patients, the postprandial ghrelin response is partly or completely lacking and it is independent of the caloric content and macronutrient composition of the meal.

Efforts to develop pharmacological treatments for obesity have increased tremendously in the last decade, spurred by the increase of obesity prevalence and its recognition of as a chronic disease with severe consequences and complications (World Health Organization, 1998). More efficient drugs are still required to combat the obesity epidemic.

Gut peptides have received growing attention for their ability to regulate many GI functions, particularly those related to food intake and digestive motility (Gourcerol and Tache 2007). In contrast to the current medicaments that affect systems relatively indiscriminately, the use of gut hormones as therapeutic agents would have the advantage of targeting only the relevant appetite control systems. It seems likely that permanent weight loss will require continuous treatment throughout the life of a patient, or at least for extended periods of time.

Ghrelin's prokinetic and orexigenic effects have opened new potential therapeutic venues for the modulation of food intake (Klok et al. 2007). At present, ghrelin is the only peripheral orexigenic signal effective after i.v. injection and/or chronic peripheral administration (Tschop et al. 2000, Wren et al. 2001). Thus, ghrelin itself may be useful orexigenic agent for the treatment of disorders accompanied by chronic malnutrition due to decreased food intake such as anorexia nervosa. Blocking or neutralization of the orexigenic action of ghrelin could be, on the other side, a reasonable approach to decrease an 
excessive food intake in obesity. However, it should be noted that appetite is regulated by numerous factors which may interact with and compensate for each other. Therefore the effectiveness of such approach has to be directly demonstrated in clinical studies. Further research is required to investigate whether ghrelin antagonists/ agonists might be suitable antiobesity/malnutrition-treating drugs that can be used in wide clinical practice.

\section{Conflict of Interest}

There is no conflict of interest.

\section{Acknowledgements}

Supported in part by MZO 000064165.

\section{References}

ALVAREZ-CASTRO P, ISIDRO ML, GARCÍA-BUELA J, DIEGUEZ C, CASANUEVA FF, CORDIDO F: Effect of acute ghrelin administration on glycaemia and insulin levels in obese patients. Diabetes Obes Metab 8: 555$560,2006$.

AROSIO M, RONCHI CL, BECK-PECCOZ P, GEBBIA C, GIAVOLI C, CAPPIELLO V, CONTE D, PERACCHI M: Effects of modified sham feeding on ghrelin levels in healthy human subjects. J Clin Endocrinol Metab 89: 5101-5104, 2004.

ASTRUP A: Dietary fat is a major player in obesity - but not the only one. Obes Rev 3: 57-58, 2002.

BALDANZI G, FILIGHEDDU N, CUTRUPI S, CATAPANO F, BONISSONI S, FUBINI A, MALAN D, BAJ G, GRANATA R, BROGLIO F, PAPOTTI M, SURICO N, BUSSOLINO F, ISGAARD J, DEGHENGHI R, SINIGAGLIA F, PRAT M, MUCCIOLI G, GHIGO E, GRAZIANI A: Ghrelin and des-acyl ghrelin inhibit cell death in cardiomyocytes and endothelial cells through ERK1/2 and PI 3-kinase/AKT. J Cell Biol 159: 1029$1037,2002$.

BRIATORE L, ANDRAGHETTI G, CORDERA R: Effect of two fasting periods of different duration on ghrelin response to a mixed meal. Nutr Metab Cardiovasc Dis 16: 471-476, 2006.

BROGLIO F, GIANOTTI L, DESTEFANIS S, FASSINO S, ABBATE DAGA G, MONDELLI V, LANFRANCO F, GOTTERO C, GAUNA C, HOFLAND L, VAN DER LELY AJ, GHIGO E: The endocrine response to acute ghrelin administration is blunted in patients with anorexia nervosa, a ghrelin hypersecretory state. Clin Endocrinol (Oxf) 60: 592-599, 2004.

CALLAHAN HS, CUMMINGS DE, PEPE MS, BREEN PA, MATTHYS CC, WEIGLE DS: Postprandial suppression of plasma ghrelin level is proportional to ingested caloric load but does not predict intermeal interval in humans. J Clin Endocrinol Metab 89: 1319-1324, 2004.

CASPER RC: Carbohydrate metabolism and its regulatory hormones in anorexia nervosa. Psychiatry Res 62: 85-96, 1996.

CHEN HY, TRUMBAUER ME, CHEN AS, WEINGARTH DT, ADAMS JR, FRAZIER EG, SHEN Z, MARSH DJ, FEIGHNER SD, GUAN XM, YE Z, NARGUND RP, SMITH RG, VAN DER PLOEG LH, HOWARD AD, MACNEIL DJ, QIAN S: Orexigenic action of peripheral ghrelin is mediated by neuropeptide Y and agoutirelated protein. Endocrinology 145: 2607-2612, 2004.

CREMONINI F, CAMILLERI M, VAZQUEZ ROQUE M, MCKINZIE S, BURTON D, BAXTER K, ZINSMEISTER AR: Obesity does not increase effects of synthetic ghrelin on human gastric motor functions. Gastroenterology 131: 1431-1439, 2006.

CUMMINGS DE: Ghrelin and the short- and long-term regulation of appetite and body weight. Physiol Bev 89: 71-84, 2006.

CUMMINGS DE, PURNELL JQ, FRAYO RS, SCHMIDOVA K, WISSE BE, WEIGLE DS: A preprandial rise in plasma ghrelin levels suggests a role in meal initiation in humans. Diabetes 50: 1714-1719, 2001.

CUMMINGS DE, WEIGLE DS, FRAYO RS, BREEN PA, MA MK, DELLINGER EP, PURNELL JQ: Plasma ghrelin levels after diet-induced weight loss or gastric bypass surgery. $N$ Engl J Med 346: 1623-1630, 2002.

CUMMINGS DE, SHANNON MH: Ghrelin and gastric bypass: is there a hormonal contribution to surgical weight loss? J Clin Endocrinol Metab 88: 2999-3002, 2003. 
DARDENNES RM, ZIZZARI P, TOLLE V, FOULON C, KIPMAN A, ROMO L, IANCU-GONTARD D, BONI C, SINET PM, THÉRÈSE BLUET M, ESTOUR B, MOUREN MC, GUELFI JD, ROUILLON F, GORWOOD P, EPELBAUM J: Family trios analysis of common polymorphisms in the obestatin/ghrelin, BDNF and AGRP genes in patients with Anorexia nervosa: association with subtype, body-mass index, severity and age of onset. Psychoneuroendocrinology 32: 106-113, 2007.

DATE Y, KOJIMA M, HOSODA H, SAWAGUCHI A, MONDAL MS, SUGANUMA T, MATSUKURA S, KANGAWA K, NAKAZATO M: Ghrelin, a novel growth hormone-releasing acylated peptide, is synthesized in a distinct endocrine cell type in the gastrointestinal tracts of rats and humans. Endocrinology 141: 42554261, 2000.

DATE Y, TOSHINAI K, KODA S, MIYAZATO M, SHIMBARA T, TSURUTA T, NIIJIMA A, KANGAWA K, NAKAZATO M: Peripheral interaction of ghrelin with cholecystokinin on feeding regulation. Endocrinology 146: 3518-3525, 2005.

DELGADO-AROS S, LOCKE GR, CAMILLERI M, TALLEY NJ, FETT S, ZINSMEISTER AR, MELTON LJ: Obesity is associated with increased risk of gastrointestinal symptoms: a population-based study. Am J Gastroenterol 99: 1801-1806, 2004.

DOLEŽALOVÁ R, LACINOVÁ Z, DOLINKOVÁ M, KLEIBLOVÁ P, HALUZÍKOVÁ D, HOUSA D, PAPEŽOVÁ H, HALUZÍK M: Changes of endocrine function of adipose tissue in anorexia nervosa: comparison of circulating levels vs. subcutaneous mRNA expression. Clin Endocrinol 67: 674-678, 2007.

DRUCE MR, SMALL CJ, BLOOM SR: Minireview: Gut peptides regulating satiety. Endocrinology 145: 2660-2665, 2004.

ENGLISH PJ, GHATEI MA, MALIK IA, BLOOM SR, WILDING JP: Food fails to suppress ghrelin levels in obese humans. J Clin Endocrinol Metab 87: 2984-2987, 2002.

ERDMANN J, LIPPL F, SCHUSDZIARRA V: Differential effect of protein and fat on plasma ghrelin levels in man. Regul Pept 116: 101-107, 2003.

ERDMANN J, TÖPSCH R, LIPPL F, GUSSMANN P, SCHUSDZIARRA V: Postprandial response of plasma ghrelin levels to various test meals in relation to food intake, plasma insulin, and glucose. J Clin Endocrinol Metab 89: 3048-3054, 2004.

FLANAGAN DE, EVANS ML, MONSOD TP, RIFE F, HEPTULLA RA, TAMBORLANE WV, SHERWIN RS: The influence of insulin on circulating ghrelin. Am J Physiol 284: E313-E316, 2003.

FRAYN KN, COPPACK SW: Insulin resistance, adipose tissue and coronary heart disease. Clin Sci (Lond) 82: 1-8, 1992.

GELONEZE B, TAMBASCIA MA, PILLA VF, GELONEZE SR, REPETTO EM, PAREJA JC: Ghrelin: a gut-brain hormone: effect of gastric bypass surgery. Obes Surg 13: 17-22, 2003.

GIOVAMBATTISTA A, GAILLARD RC, SPINEDI E: Ghrelin gene-related peptides modulate rat white adiposity. Vitam Horm 77: 171-205, 2008.

GOURCEROL G, TACHÉ Y: Obestatin - a ghrelin-associated peptide that does not hold its promise to suppress food intake and motility. Neurogastroenterol Motil 19: 161-165, 2007.

GREENMAN Y, GOLANI N, GILAD S, YARON M, LIMOR R, STERN N: Ghrelin secretion is modulated in a nutrient- and gender-specific manner. Clin Endocrinol (Oxf) 60: 382-388, 2004.

HANUSCH-ENSERER U, CAUZA E, BRABANT G, DUNKY A, ROSEN H, PACINI G, TÜCHLER H, PRAGER R, RODEN M: Plasma ghrelin in obesity before and after weight loss after laparoscopical adjustable gastric banding. J Clin Endocrinol Metab 89: 3352-3358, 2004.

HARADA T, NAKAHARA T, YASUHARA D, KOJIMA S, SAGIYAMA KI, AMITANI H, LAVIANO A, NARUO T, INUI A: Obestatin, acyl ghrelin, and des-acyl ghrelin responses to an oral glucose tolerance test in the restricting type of anorexia nervosa. Biol Psychiatry 63: 245-247, 2008.

HEATH RB, JONES R, FRAYN KN, ROBERTSON MD: Vagal stimulation exaggerates the inhibitory ghrelin response to oral fat in humans. J Endocrinol 180: 273-281, 2004.

HOLST B, EGEROD KL, SCHILD E, VICKERS SP, CHEETHAM S, GERLACH LO, STORJOHANN L, STIDSEN CE, JONES R, BECK-SICKINGER AG, SCHWARTZ TW: GPR39 signaling is stimulated by zinc ions but not by obestatin. Peptides 27: 2811-2819, 2006. 
HOTTA M, OHWADA R, KATAKAMI H, SHIBASAKI T, HIZUKA N, TAKANO K: Plasma levels of intact and degraded ghrelin and their responses to glucose infusion in anorexia nervosa. J Clin Endocrinol Metab 89: 5707-5712, 2004.

HOUSOVÁ J, ANDERLOVÁ K, KŘÍŽOVÁ J, HALUZÍKOVÁ D, KŘEMEN J, KUMŠTÝŘOVÁ T, PAPEŽOVÁ H, HALUZÍK M: Serum adiponectin and resistin concentrations in patients with restrictive and binge/purge form of anorexia nervosa and bulimia nervosa. J Clin Endocrinol Metab. 90: 1366-1370, 2005.

JANAS-KOZIK M, KRUPKA-MATUSZCZYK I, MALINOWSKA-KOLODZIEJ I, LEWIN-KOWALIK J: Total ghrelin plasma level in patients with the restrictive type of anorexia nervosa. Regul Pept 140: 43-46, 2007.

KLOK MD, JAKOBSDOTTIR S, DRENT ML: The role of leptin and ghrelin in the regulation of food intake and body weight in humans: a review. Obes Rev 8: 21-34, 2007.

KOJIMA M, HOSODA H, DATE Y, NAKAZATO M, MATSUO H, KANGAWA K: Ghrelin is a growth-hormonereleasing acylated peptide from stomach. Nature 402: 656-660, 1999.

KOTIDIS EV, KOLIAKOS G, PAPAVRAMIDIS TS, PAPAVRAMIDIS ST: The effect of biliopancreatic diversion with pylorus-preserving sleeve gastrectomy and duodenal switch on fasting serum ghrelin, leptin and adiponectin levels: is there a hormonal contribution to the weight-reducing effect of this procedure? Obes Surg 16: 554-559, 2006.

LANGER FB, REZA HODA MA, BOHDJALIAN A, FELBERBAUER FX, ZACHERL J, WENZL E, SCHINDLER K, LUGER A, LUDVIK B, PRAGER G: Sleeve gastrectomy and gastric banding: effects on plasma ghrelin levels. Obes Surg 15: 1024-1029, 2005.

LE ROUX CW, BLOOM SR: Peptide YY, appetite and food intake. Proc Nutr Soc 64: 213-216, 2005.

LEIDY HJ, GARDNER JK, FRYE BR, SNOOK ML, SCHUCHERT MK, RICHARD EL, WILLIAMS NI: Circulating ghrelin is sensitive to changes in body weight during a diet and exercise program in normal-weight young women. J Clin Endocrinol Metab 89: 2659-2664, 2004.

LEONETTI F, SILECCHIA G, IACOBELLIS G, RIBAUDO MC, ZAPPATERRENO A, TIBERTI C, IANNUCCI CV, PERROTTA N, BACCI V, BASSO MS, BASSO N, DI MARIO U: Different plasma ghrelin levels after laparoscopic gastric bypass and adjustable gastric banding in morbid obese subjects. J Clin Endocrinol Metab 88: 4227-4231, 2003.

MACKELVIE KJ, MENEILLY GS, ELAHI D, WONG AC, BARR SI, CHANOINE JP: Regulation of appetite in lean and obese adolescents after exercise: role of acylated and desacyl ghrelin. J Clin Endocrinol Metab 92:648654, 2007.

MARZULLO P, CAUMO A, SAVIA G, VERTI B, WALKER GE, MAESTRINI S, TAGLIAFERRI A, Di BLASIO AM, LIUZZI A: Predictors of postabsorptive ghrelin secretion after intake of different macronutrients. $J$ Clin Endocrinol Metab 91: 4124-4130, 2006.

MCCOWEN KC, MAYKEL JA, BISTRIAN BR, LING PR: Circulating ghrelin concentrations are lowered by intravenous glucose or hyperinsulinemic euglycemic conditions in rodents. J Endocrinol 175: R7-R11, 2002.

MCLAUGHLIN T, ABBASI F, LAMENDOLA C, FRAYO RS, CUMMINGS DE: Plasma ghrelin concentrations are decreased in insulin-resistant obese adults relative to equally obese insulin-sensitive controls. $J$ Clin Endocrinol Metab 89: 1630-1635, 2004.

MILJIC D, PEKIC S, DJUROVIC M, DOKNIC M, MILIC N, CASANUEVA FF, GHATEI M, POPOVIC V: Ghrelin has partial or no effect on appetite, growth hormone, prolactin, and cortisol release in patients with anorexia nervosa. J Clin Endocrinol Metab 91: 1491-1495, 2006.

MISRA M, MILLER KK, HERZOG DB, RAMASWAMY K, AGGARWAL A, ALMAZAN C, NEUBAUER G, BREU J, KLIBANSKI A: Growth hormone and ghrelin responses to an oral glucose load in adolescent girls with anorexia nervosa and controls. J Clin Endocrinol Metab 89: 1605-1612, 2004.

MISRA M, MILLER KK, KUO K, GRIFFIN K, STEWART V, HUNTER E, HERZOG DB, KLIBANSKI A: Secretory dynamics of ghrelin in adolescent girls with anorexia nervosa and healthy adolescents. Am J Physiol 289: E347-E356, 2005.

MÖHLIG M, SPRANGER J, OTTO B, RISTOW M, TSCHÖP M, PFEIFFER AF: Euglycemic hyperinsulinemia, but not lipid infusion, decreases circulating ghrelin levels in humans. J Endocrinol Invest 25: RC36-RC38, 2002. 
MONTELEONE P, BENCIVENGA R, LONGOBARDI N, SERRITELLA C, MAJ M: Differential responses of circulating ghrelin to high-fat or high-carbohydrate meal in healthy women. J Clin Endocrinol Metab 88: 5510-5514, 2003.

MORAN TH: Gut peptide signaling in the controls of food intake. Obesity (Silver Spring) 14: 250S-253S, 2006.

MORAN TH, NOAKES M, CLIFTON PM, WITTERT GA, TOMLINSON L, GALLETLY C, LUSCOMBE ND, NORMAN RJ: Ghrelin and measures of satiety are altered in polycystic ovary syndrome but not differentially affected by diet composition. J Clin Endocrinol Metab 89: 3337-3344, 2004.

MORÍNIGO R, CASAMITJANA R, MOIZÉ V, LACY AM, DELGADO S, GOMIS R, VIDAL J: Short-term effects of gastric bypass surgery on circulating ghrelin levels. Obes Res 12: 1108-1116, 2004.

MORPURGO PS, RESNIK M, AGOSTI F, CAPPIELLO V, SARTORIO A, SPADA A: Ghrelin secretion in severely obese subjects before and after a 3-week integrated body mass reduction program. J Endocrinol Invest 26: 723$727,2003$.

MUCCIOLI G, TSCHÖP M, PAPOTTI M, DEGHENGHI R, HEIMAN M, GHIGO E: Neuroendocrine and peripheral activities of ghrelin: implications in metabolism and obesity. Eur J Pharmacol 440: 235-254, 2002.

MUNDINGER TO, CUMMINGS DE, TABORSKY GJ: Direct stimulation of ghrelin secretion by sympathetic nerves. Endocrinology 147: 2893-2901, 2006.

MURDOLO G, LUCIDI P, Di LORETO C, PARLANTI N, DE CICCO A, FATONE C, FANELLI CG, BOLLI GB, SANTEUSANIO F, DE FEO P: Insulin is required for prandial ghrelin suppression in humans. Diabetes 52: 2923-2927, 2003.

NAKAGAWA E, NAGAYA N, OKUMURA H, ENOMOTO M, OYA H, ONO F, HOSODA H, KOJIMA M, KANGAWA K: Hyperglycaemia suppresses the secretion of ghrelin, a novel growth-hormone-releasing peptide: responses to the intravenous and oral administration of glucose. Clin Sci (Lond) 103: 325-328, 2002.

NAKAHARA T, KOJIMA S, TANAKA M, YASUHARA D, HARADA T, SAGIYAMA K, MURANAGA T, NAGAI N, NAKAZATO M, NOZOE S, NARUO T, INUI A: Incomplete restoration of the secretion of ghrelin and PYY compared to insulin after food ingestion following weight gain in anorexia nervosa. $J$ Psychiatr Res 41 : 814-820, 2007.

NAKAI Y, HOSODA H, NIN K, OOYA C, HAYASHI H, AKAMIZU T, KANGAWA K: Plasma levels of active form of ghrelin during oral glucose tolerance test in patients with anorexia nervosa. Eur J Endocrinol 149: R1-R3, 2003.

NAKAZATO M, MURAKAMI N, DATE Y, KOJIMA M, MATSUO H, KANGAWA K, MATSUKURA S: A role for ghrelin in the central regulation of feeding. Nature 409: 194-198, 2001.

NEDVÍDKOVÁ J, KRYKORKOVÁ I, BARTÁK V, PAPEŽOVÁ H, GOLD PW, ALESCI S, PACÁK K: Loss of meal-induced decrease in plasma ghrelin levels in patients with anorexia nervosa. J Clin Endocrinol Metab 88: 1678-1682, 2003.

NOGUEIRAS R, PFLUGER P, TOVAR S, ARNOLD M, MITCHELL S, MORRIS A, PEREZ-TILVE D, VÁZQUEZ MJ, WIEDMER P, CASTAÑEDA TR, DIMARCHI R, TSCHÖP M, SCHURMANN A, JOOST HG, WILLIAMS LM, LANGHANS W, DIÉGUEZ C: Effects of obestatin on energy balance and growth hormone secretion in rodents. Endocrinology 148: 21-26, 2007.

OTTO B, CUNTZ U, FRUEHAUF E, WAWARTA R, FOLWACZNY C, RIEPL RL, HEIMAN ML, LEHNERT P, FICHTER M, TSCHÖP M: Weight gain decreases elevated plasma ghrelin concentrations of patients with anorexia nervosa. Eur J Endocrinol 145: 669-673, 2001.

OTTO B, TSCHÖP M, FRÜHAUF E, HELDWEIN W, FICHTER M, OTTO C, CUNTZ U: Postprandial ghrelin release in anorectic patients before and after weight gain. Psychoneuroendocrinology 30: 577-581, 2005.

OVERDUIN J, FRAYO RS, GRILL HJ, KAPLAN JM, CUMMINGS DE: Role of the duodenum and macronutrient type in ghrelin regulation. Endocrinology 146: 845-850, 2005.

PETERSENN S: Growth hormone secretagogues and ghrelin: an update on physiology and clinical relevance. Horm Res 58: 56-61, 2002.

PURNELL JQ, CUMMINGS D, WEIGLE DS: Changes in 24-h area-under-the-curve ghrelin values following dietinduced weight loss are associated with loss of fat-free mass, but not with changes in fat mass, insulin levels or insulin sensitivity. Int J Obes (Lond) 31: 385-389, 2007. 
REAVEN GM: The metabolic syndrome: is this diagnosis necessary? Am J Clin Nutr 83: 1237-1247, 2006.

ROBERTSON MD, HENDERSON RA, VIST GE, RUMSEY RD: Plasma ghrelin response following a period of acute overfeeding in normal weight men. Int J Obes Relat Metab Disord 28: 727-733, 2004.

ROMON M, GOMILA S, HINCKER P, SOUDAN B, DALLONGEVILLE J: Influence of weight loss on plasma ghrelin responses to high-fat and high-carbohydrate test meals in obese women. $J$ Clin Endocrinol Metab 91: 1034-1041, 2006.

RÜTER J, KOBELT P, TEBBE JJ, AVSAR Y, VEH R, WANG L, KLAPP BF, WIEDENMANN B, TACHÉ Y, MÖNNIKES H: Intraperitoneal injection of ghrelin induces Fos expression in the paraventricular nucleus of the hypothalamus in rats. Brain Res 991: 26-33, 2003.

SAAD MF, BERNABA B, HWU CM, JINAGOUDA S, FAHMI S, KOGOSOV E, BOYADJIAN R: Insulin regulates plasma ghrelin concentration. J Clin Endocrinol Metab 87: 3997-4000, 2002.

SHIIYA T, NAKAZATO M, MIZUTA M, DATE Y, MONDAL MS, TANAKA M, NOZOE S, HOSODA H, KANGAWA K, MATSUKURA S: Plasma ghrelin levels in lean and obese humans and the effect of glucose on ghrelin secretion. J Clin Endocrinol Metab 87: 240-244, 2002.

SCHWARTZ MW, MORTON GJ: Obesity: keeping hunger at bay. Nature 418: 595-597, 2002.

SORIANO-GUILLÉN L, BARRIOS V, CAMPOS-BARROS A, ARGENTE J: Ghrelin levels in obesity and anorexia nervosa: effect of weight reduction or recuperation. J Pediatr 144: 36-42, 2004.

ST-PIERRE DH, KARELIS AD, CODERRE L, MALITA F, FONTAINE J, MIGNAULT D, BROCHU M, BASTARD JP, CIANFLONE K, DOUCET E, IMBEAULT P, RABASA-LHORET R: Association of acylated and nonacylated ghrelin with insulin sensitivity in overweight and obese postmenopausal women. $J$ Clin Endocrinol Metab 92: 264-269, 2007.

TANAKA M, NARUO T, YASUHARA D, TATEBE Y, NAGAI N, SHIIYA T, NAKAZATO M, MATSUKURA S, NOZOE S: Fasting plasma ghrelin levels in subtypes of anorexia nervosa. Psychoneuroendocrinology 28: 829835, 2003.

TANAKA M, NAKAHARA T, KOJIMA S, NAKANO T, MURANAGA T, NAGAI N, UENO H, NAKAZATO M, NOZOE S, NARUO T: Effect of nutritional rehabilitation on circulating ghrelin and growth hormone levels in patients with anorexia nervosa. Regul Pept 122: 163-168, 2004.

TASSONE F, BROGLIO F, DESTEFANIS S, ROVERE S, BENSO A, GOTTERO C, PRODAM F, ROSSETTO R, GAUNA C, VAN DER LELY AJ, GHIGO E, MACCARIO M: Neuroendocrine and metabolic effects of acute ghrelin administration in human obesity. J Clin Endocrinol Metab 88: 5478-5483, 2003.

TRITOS NA, MUN E, BERTKAU A, GRAYSON R, MARATOS-FLIER E, GOLDFINE A: Serum ghrelin levels in response to glucose load in obese subjects post-gastric bypass surgery. Obes Res 11: 919-924, 2003.

TROISI A, DI LORENZO G, LEGA I, TESAURO M, BERTOLI A, LEO R, IANTORNO M, PECCHIOLI C, RIZZA S, TURRIZIANI M, LAURO R, SIRACUSANO A: Plasma ghrelin in anorexia, bulimia, and binge-eating disorder: relations with eating patterns and circulating concentrations of cortisol and thyroid hormones. Neuroendocrinology 81: 259-266, 2005.

TSCHÖP M, SMILEY DL, HEIMAN ML: Ghrelin induces adiposity in rodents. Nature 407: 908-913, 2000.

TSCHÖP M, WAWARTA R, RIEPL RL, FRIEDRICH S, BIDLINGMAIER M, LANDGRAF R, FOLWACZNY C: Post-prandial decrease of circulating human ghrelin levels. J Endocrinol Invest 24: RC19-RC21, 2001.

WEIGLE DS, CUMMINGS DE, NEWBY PD, BREEN PA, FRAYO RS, MATTHYS CC, CALLAHAN HS, PURNELL JQ: Roles of leptin and ghrelin in the loss of body weight caused by a low fat, high carbohydrate diet. J Clin Endocrinol Metab 88: 1577-1586, 2003.

WILLIAMS DL, CUMMINGS DE, GRILL HJ, KAPLAN JM: Meal-related ghrelin suppression requires postgastric feedback. Endocrinology 144: 2765-2767, 2003.

WREN AM, SEAL LJ, COHEN MA, BRYNES AE, FROST GS, MURPHY KG, DHILLO WS, GHATEI MA, BLOOM SR: Ghrelin enhances appetite and increases food intake in humans. $J$ Clin Endocrinol Metab 86: 5992-5995, 2001. 
YAMAMOTO D, IKESHITA N, DAITO R, HERNINGTYAS EH, TODA K, TAKAHASHI K, IIDA K, TAKAHASHI Y, KAJI H, CHIHARA K, OKIMURA Y: Neither intravenous nor intracerebroventricular administration of obestatin affects the secretion of GH, PRL, TSH and ACTH in rats. Regul Pept 138: 141-144, 2007.

ZHANG JV, REN PG, AVSIAN-KRETCHMER O, LUO CW, RAUCH R, KLEIN C, HSUEH AJ: Obestatin, a peptide encoded by the ghrelin gene, opposes ghrelin's effects on food intake. Science 310: 996-999, 2005. 